\title{
SEGUNDA CHAMADA: A REPRESENTAÇÃO DO PROFESSOR DE ARTE NA EDUCAÇÃO DE JOVENS E ADULTOS
}

\section{Second Call: the Representation of the Art Teacher on Youth and Adult Education}

\author{
Judivan Alves Ferreira ${ }^{1}$
}

\begin{abstract}
Resumo: Os produtos culturais audiovisuais constituem espaços privilegiados para pensarmos culturas, identidades culturais e educação. O objetivo deste trabalho foi analisar a representação da personagem Marco André, professor de arte, na série Segunda Chamada, com vistas à problematização do lugar da arte e do ensino dela na educação de jovens e adultos da série em tela. Para isso, abordou-se questões relacionadas à escola e à qualidade do ensino público no Brasil; à educação de jovens e adultos enquanto modalidade de ensino; e, à representação do professor de arte na série supracitada no intuito de discutir arte e ensino de arte. Metodologicamente, utilizou-se a análise fílmica à luz dos estudos culturais, tendo como arcabouço teórico os estudos relativos à arte, à educação e ao ensino de arte. Depreendeu-se que a arte, no contexto escolar, contribui para incitar o pensamento e, neste sentido, ensiná-la é uma forma de oportunizar experiências e conhecimentos que possibilitam aos/às estudantes a apreciação, a reflexão e a elaboração artística de suas realidades.
\end{abstract}

Palavras-chave: Segunda Chamada. Educação de Jovens e Adultos. Arte e Ensino de Arte.

\begin{abstract}
Audiovisual culture products are privileged spaces to thinking about cultures, cultural identities and education. The objective of this work was to analyze the representation of the character Marco André, art teacher, in the Brazilian tv show Segunda Chamada (Second Call, in English), with a sight to problematizing the place of art and its instruction on the young people education and adults in the tv show on screen. For this purpose, issues related to school and the public education quality in Brazil were approached; the education of young people and adults as a teaching modality; and, the representation of the art teacher in the tv show mentioned above in order to discuss art and art teaching. Methodologically, film analysis was used in the light of cultural studies, with the theoretical framework of studies related to art, education and art instruction. It was found that art, in the school context, contributes to promote insights and, thereby the instruction of art is a way to provide experiences and knowledge what enables students to appreciate, reflect and develop their artistic realities.
\end{abstract}

Keywords: Second Call. Youth and adult education. Art and art teaching.

\footnotetext{
${ }^{1}$ Professor da Educação Básica vinculado à Secretaria Municipal de Educação de Goiás - GO. De formação acadêmica híbrida, transita entre a Comunicação Social, a Museologia e a Educação. Especialista em Gênero e Diversidade na Escola e em Processos e Produtos Criativos. Orcid: https://orcid.org/0000-0002-1184-3797. Email: judiferrer@gmail.com
} 


\section{Vamos começar...}

Como o professor e a disciplina de arte são representados em Segunda Chamada? Foi no intuito de responder a essa pergunta-problema que surgiu esse trabalho, o qual objetivou analisar a representação da personagem Marco André (interpretado por Silvio Guindane), professor de arte, em Segunda Chamada com vistas à problematização do lugar da arte e do ensino dela na educação de jovens e adultos (EJA) da série em tela. Para atingi-lo foram estabelecidos os seguintes objetivos secundários: assistir à série; levantar bibliografia pertinente ao tema e realizar análise fílmica à luz dos estudos culturais.

Segunda Chamada é uma série televisiva, veiculada pela Globo em 2019 e disponível na Globoplay, sua plataforma digital com streaming de vídeos. A série - inspirada na peça teatral Conselho de Classe, do dramaturgo Bilac ([2013], 2016) - foi escrita e roteirizada por Carla Faour e Julia Spadaccini com contribuições de Bilac e com direção de arte de Joana Jabace. Tanto Conselho de Classe (2013) quanto Segunda Chamada (2019) se apropriaram das demandas da realidade da educação brasileira em seus processos criativos. Na peça, vemos em cena uma reunião de professores da Escola Estadual Dias Gomes ser desestabilizada pela chegada de um novo diretor. Essa nova presença levou à escola outra dinâmica organizacional e fez eclodir dilemas éticos e pessoais em meio a decisões que se confundem nas relações de poder na e da escola enfatizando um estado agônico da educação brasileira (BILAC, 2016). A série, por sua vez, apresenta a rotina de professores e estudantes da Escola Estadual Carolina Maria de Jesus e traz à tona a educação de jovens e adultos, "parte mais negligenciada do sistema educacional, a partir de um universo de pessoas que representa um microcosmo do Brasil" (GIANNINI, 2019, online).

Quem dá vida às professoras (Figura 01) da série são as atrizes Debora Bloch, Hermila Guedes e Thalita Carauta, que são, respectivamente, Lúcia Rocha - língua portuguesa, Sônia Carrasco - história e Eliete Sabá - matemática. Juntam-se ao corpo docente os professores Marco André da Silva, de arte; Paulo Moreira, de literatura, e o diretor Jaci Araújo que são interpretados, respectivamente, por Guindane, Caio Blat e Paulo Gorgulho.

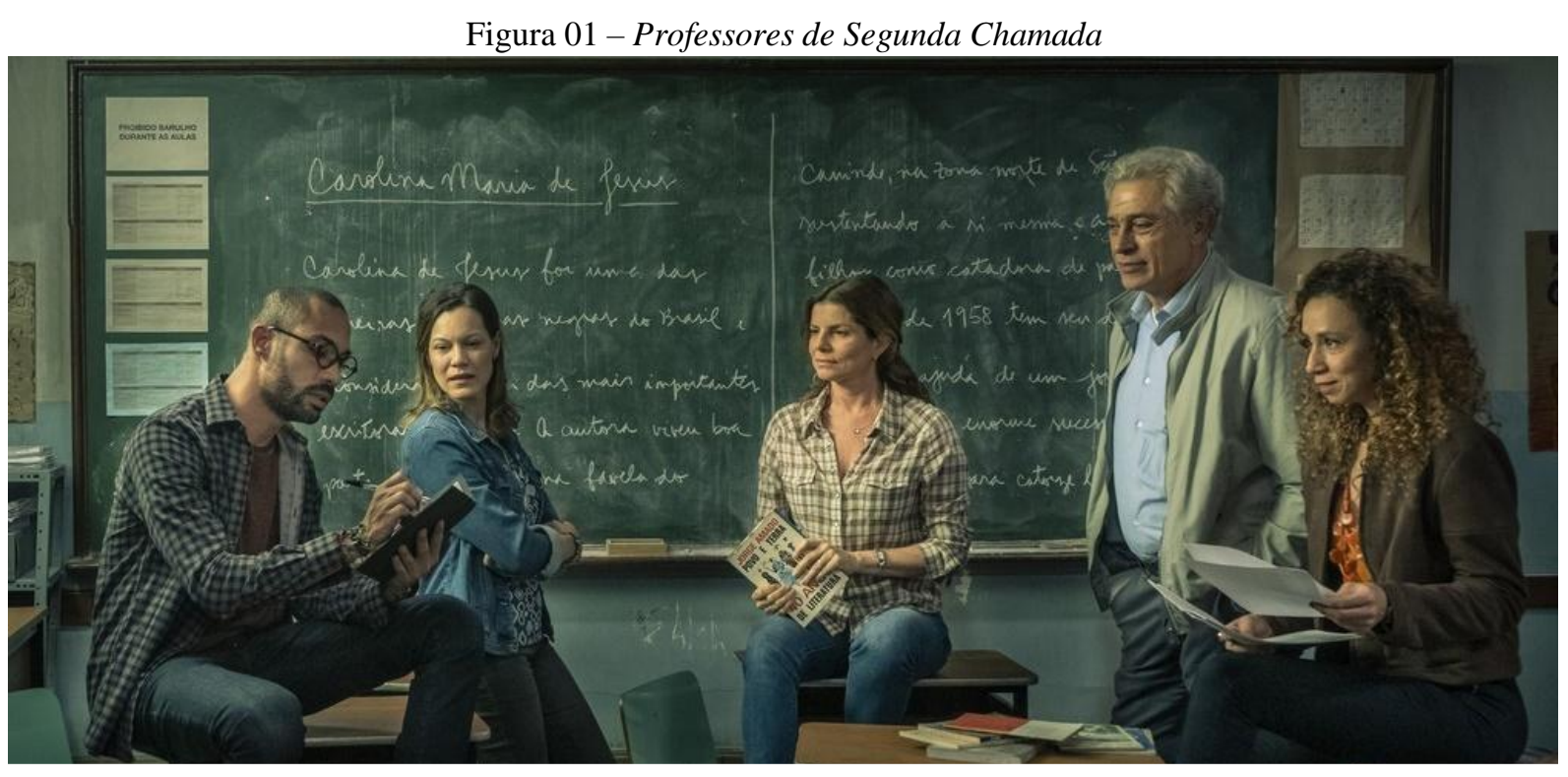

Da esquerda para a direita: Marco André, Sônia, Lúcia, Jaci e Eliete. Foto: Mauricio Fidalgo/O Globo.

A cada episódio, de um total de onze, somos convidados/as (ora como estudante, ora como professor/a, ora como gestor/a, ora como sociedade civil) a pensar e a problematizar 
inúmeras questões relacionadas à educação como direito à escola para todos/as, à escolarização de jovens e adultos, à docência nessa modalidade de ensino, aos acessos à cidade e à cidadania. Além disso, em Segunda Chamada, somos convidados/as a olhar e a refletir sobre partes do nosso cotidiano que devido à correria do dia a dia e à sociedade do cansaço (HAN, 2015) acabam passando despercebidas ou ignoradas, quando, em um cenário ideal, nem deveriam existir como, por exemplo, a homo-lesbo-transfobia, o racismo, a xenofobia, o desemprego, a intolerância religiosa e as abissais desigualdades sociais ${ }^{2}$, que acabam entrando em contato na escola e gerando fricções entre a comunidade escolar.

'Comportamento geral', música-tema da série, nos ajuda nesse exercício de reflexão. "Você merece/ Você merece/ Tudo vai bem, tudo legal/ Cerveja, samba e amanhã, seu Zé/ Se acabarem teu carnaval" (GONZAGUINHA, 1973). Longe de fazer uma análise musicológica da canção, que na série ganhou a interpretação de Elza Soares (2019), seu Zé pode ser entendido como o povo brasileiro que, assim como 'você', nota que as coisas estão erradas e, às vezes, não se preocupa e noutras luta para que elas melhorem. Os produtos culturais - como os conteúdos midiáticos e as narrativas audiovisuais e cinematográficas - nos ajudam a pensar essas questões, pois constituem espaços privilegiados para pensarmos culturas, identidades culturais e educação. Tais produtos atuam, segundo Ferreira (2014, p. 216), "como elementos representativos da ordem do mundo e constitutivos da subjetividade e das representações sociais". Eles contribuem para a formação do imaginário - aqui entendido à luz dos estudos de Castoriadis (1982) e Cunha (2006, p. 14) quando o pensam como "o lugar de produção de sentido, aquilo que faz significar" - que não apenas nos faz pensar sobre algo ou alguma coisa, mas nos faz também criar a própria realidade.

Digo isso, pois - considerando a análise fílmica - os produtos culturais audiovisuais e cinematográficos apresentam um universo próprio (FERREIRA, 2017), que Caseti e Di Chio (1996) chamam de 'mundo possível'. Para eles,

este mundo possível não está isento de relações com o 'mundo real': não somente porque muitas vezes se constrói através de fragmentos da vida concreta, com seus objetos, seus corpos, seus ambientes, etc., mas também porque pode continuar fazendo referência a esta vida concreta, apresentando seu próprio universo como mais próximo ou mais longe da 'realidade'. (CASSETI; DI CHIO, 1996, p. 165).

Ou seja, os produtos culturais audiovisuais e cinematográficos são e podem ser 'inspirados' também na realidade e, ao passo que Escoteguy et. al. (2007) nos chamam atenção para que não encaremos as características das personagens de um filme como realidade, mas como representações de possíveis realidades, Motta (2012) defende que as narrativas, além de representar, organizam e ajudam a constituir a realidade. Entretanto, tal como pontua Silva (2010) tais produtos culturais não devem ser entendidos como uma fonte única de verdade. Eles carecem de análises.

A análise de um filme - e aqui estendo essa leitura para outros produtos culturais audiovisuais - pode, segundo Vanoye e Goliot-Lété (1994), significar tanto a atividade de analisar 'filmicamente' quanto o produto desta análise. Nesse sentido, trata-se de um processo

\footnotetext{
${ }^{2}$ O Brasil, segundo Silvio Almeida, é um país que naturalizou a desigualdade e "normalizou a desgraça, a miséria, a morte das pessoas" (ALMEIDA, 2020, online), sobretudo, as negras. Para ele, o racismo faz parte de todos os projetos e processos educacionais e se não fosse a educação, o racismo não teria se reproduzido. A educação não é só a solução, ela também é o problema e, muitas vezes, ela ajuda a encobrir a desigualdade profunda que existe no Brasil (ALMEIDA, 2018).
} 
que se constitui de dois momentos: a descrição e a interpretação. Dessa forma, a série Segunda Chamada foi aqui entendida como uma possibilidade de observar a realidade ou cenas que nos possibilitaram pensá-la a partir das análises observacional e crítica. Esta tendo como mote o desejo de possibilitar que as pessoas pensem sobre as influências recíprocas da linguagem e da estrutura social e aquela, no sentido de observar uma dada realidade em que, enquanto observadores, construímos significados para nós mesmos. "Por meio da linguagem cinematográfica/audiovisual, dirigimos o nosso olhar, simpatizamos ou repudiamos as narrativas e rejeitamos as personagens ou nos identificamos com elas" (FERREIRA, 2017, p. 110). Sendo assim, o cinema e o audiovisual passam "a desempenhar também um papel histórico e antropológico, na medida em que constrói não apenas a representação da sociedade da qual faz parte, de seu tempo histórico, mas também a do Outro" (FERREIRA; SOUZA, 2015 , p. 2). Compete mencionar que a série em discussão não foi utilizada aqui como ilustração de teorias da educação, o intuito foi pensá-la em diálogo com a realidade que nos foi apresentada e vivida.

Ante o exposto, o artigo se estrutura em três partes nas quais são expostas e problematizadas questões relacionadas à: escola e à qualidade do ensino público no Brasil; educação de jovens e adultos enquanto modalidade de ensino; e a representação do professor de arte em Segunda Chamada com vistas à reflexão e discussão do ensino de arte na EJA. Além disso, são feitas as considerações que encerram o artigo, mas não a discussão.

\section{2 "Bem-vindo ao paraíso"}

É caminhando com Lúcia, professora de língua portuguesa, que entramos pela primeira vez na Escola Estadual Carolina Maria de Jesus (Figura 02). Ela, a escola pública, é a grande personagem de Segunda Chamada.

Figura 02 - Fachada da Escola Estadual Carolina Maria de Jesus e a própria escritora

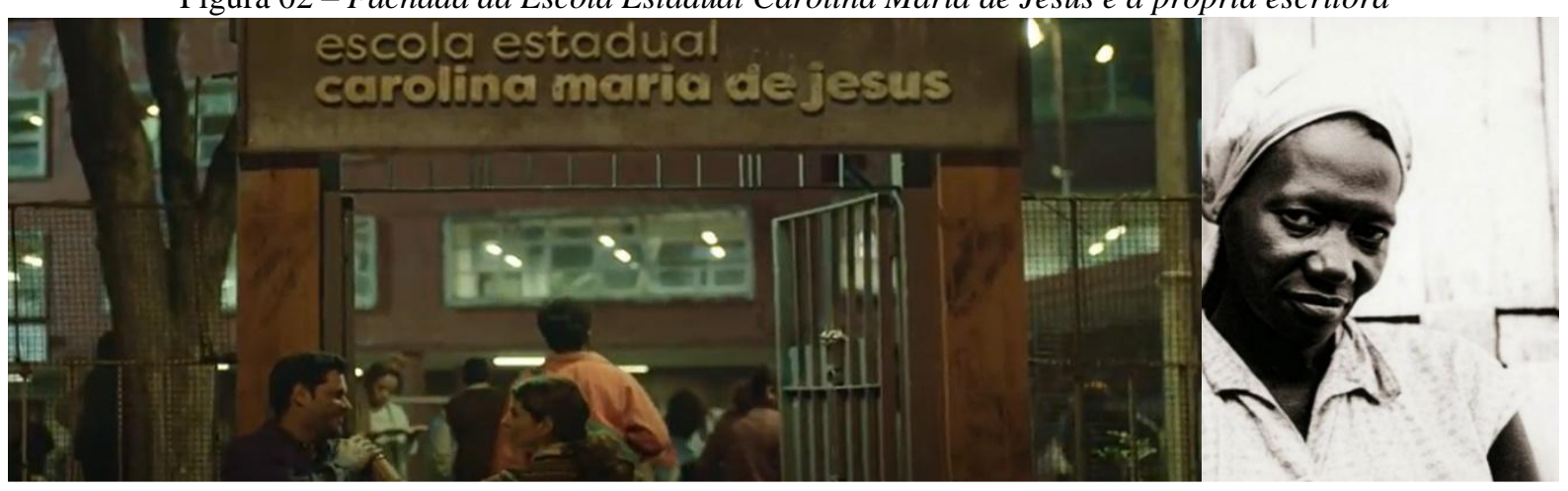

Fonte: Frame extraído de Segunda Chamada (2019) e Foto de Carolina Maria de Jesus

O nome da escola, que é fictícia, mas bem que poderia ser real, é uma referência e uma homenagem a uma das mais brilhantes escritoras de nossa língua: Carolina Maria de Jesus. Mulher, negra, migrante, favelada, catadora de papel e de uma "estrondosa e ilimitada genialidade" (GUIMARÃES, 2014, p. 77) que, durante muito tempo (e em pequena ou grande proporção isso ainda persiste) foi abnegada pelo cânone literário brasileiro na tentativa de apagamento e até mesmo anulação de sua escrita. Para a nossa sorte (e talvez essa não seja a palavra) e das gerações futuras, a política do apagamento e do esquecimento, embora tenha atrasado e até mesmo silenciado por um tempo a voz da autora, não conseguiu apagar a imagem 
e os escritos de existência como resistência de Carolina. Em uma das cenas da aula de língua portuguesa, já no primeiro capítulo, vemos a professora em sala de aula perguntar:

[Lúcia] Quem sabe me dizer quem foi a Carolina Maria de Jesus? [Vítor] Foi uma escritora negra? [Lúcia] Isso Vítor. É a autora do livro que a gente vai estudar esse semestre. 'Quarto de Despejo'. A Carolina Maria foi a primeira mulher negra a publicar um livro no Brasil. Criou os quatro filhos trabalhando como catadora de papel. Vocês podem imaginar quanto preconceito ela sofreu? Imagina se ela tivesse desistido diante das dificuldades? A gente teria perdido uma das maiores autoras brasileiras. Eu vou ler um trechinho aqui de uma entrevista dela. Quando perguntaram para ela o motivo pra ela escrever um livro, ela respondeu: 'quando eu não tinha nada o que comer em vez de xingar, eu escrevia'. Não é à toa que a nossa escola chama Carolina Maria de Jesus. Todo mundo aqui já levou muito não na vida. Todo mundo que tá aqui já levou porta fechada. Essa escola pode ser a nossa segunda chance, gente. Quem aqui já foi seguido de perto em uma loja por um segurança? E quem já levou dura da polícia sem motivo nenhum? [Vítor] Isso acontece comigo quase todo dia. [Lúcia] E quem é que já se sentiu constrangido por entrar em um elevador social? E quem já foi agredido só por entrar num banheiro? A gente já tem uma batalha todo dia lá fora. Aqui dentro dessa escola todo mundo veste a mesma camisa. (SEGUNDA CHAMADA, 2019).

A fala de Lúcia, além de contextualizar o ambiente da escola e o perfil dos/as estudantes que nela estudam, conclui uma sequência de cenas na qual a estudante Natasha (Linn da Quebrada) é vítima de violência física e simbólica por utilizar o banheiro da escola. Louro (1997) nos diz que de diferenças, distinções e desigualdades, a escola entende. Para a autora,

desde seus inícios, a instituição escolar exerceu uma ação distintiva. Ela se incumbiu de separar os sujeitos - tornando aqueles que nela entravam distintos dos outros, os que a ela não tinham acesso. Ela dividiu também, internamente, os que lá estavam, através de múltiplos mecanismos de classificação, ordenamento, hierarquização. (LOURO, 1997, p. 57).

Ao passo que a escola, que nos foi legada pela sociedade ocidental, inicialmente, tenha separado as pessoas a partir de seus marcadores sociais, ela vai, paulatinamente, sendo requisitada e ocupada por aquelas que em um passado, não muito distante, tinham o acesso negado a ela. Tais pessoas e a fala de Lúcia corroboram, veem na escola a possibilidade de uma segunda chance. "A escola é para esses meninos o sonho de uma vida melhor. Mas, às vezes, a vida é muito dura pra sonhar", afirma Lúcia em uma cena (SEGUNDA CHAMADA, 2019). Para Silvio (interpretado por José Dumont), 68 anos, estudante em situação de rua retratado na série e em diálogo com o professor Marco André, a escola é muito boa. Nas palavras dele:

[Silvio] Eu tomei outro rumo depois q eu consegui uma vaga. A gente olhando assim, parece um ninho abandonado. Mas é aqui que os livros chocam suas leituras, sabe? [Marco André] Toda escola é especial, né? Como você disse: muda o rumo das pessoas. [Silvio] Muda... (SEGUNDA CHAMADA, 2019).

Compete mencionar que o ingresso dessas pessoas no ambiente escolar levou transformações à escola, seja em sua organização e gestão, seja na reformulação dos currículos, seja na formação inicial e continuada de docentes (LOURO, 1997; SILVA, 2002) tornando a escola um ambiente diverso e com diferenças que, quiçá, vê a educação como emancipadora e como prática da liberdade, na qual ao passo que educa "aumenta a nossa capacidade de ser livres" (HOOKS, 2019, p. 13) e transforma e muda nossas vidas, pois "se o objetivo da escola 
é produzir sujeitos, seu objeto de trabalho (educando) precisa necessariamente ser sujeito" (PARO, 2012, p. 71). Tal afirmativa nos conduz à discussão sobre a qualidade da escola pública no Brasil (Figura 03).

Paro (2012, p. 56) pontua que "é muito comum dizer-se que, no Brasil, resolvemos o problema escolar com relação à quantidade, mas ainda não temos qualidade", ou seja, temos escolas edificadas (e algumas com sérios problemas de infraestrutura, como vemos em Segunda Chamada), mas ainda precisamos avançar na qualidade do ensino e entender que, conforme nos lembra a série, a "educação não é um gasto, é investimento" (SEGUNDA CHAMADA, 2019), que não pode ser entregue "às variações do mercado e às boas intenções de amadores" (RAVITCH, 2011, p. 248).

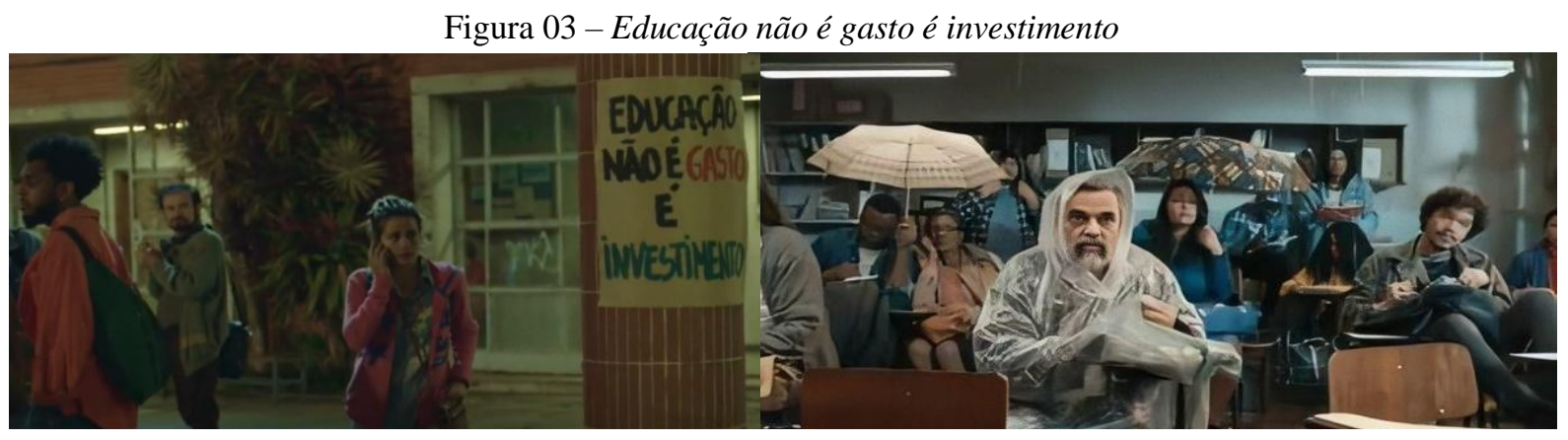

Fonte: Frame extraído de Segunda Chamada (2019)

Esse processo de mudança nem sempre é fácil, pois temos uma escola que é imaginada como modelo ideal a ser atingido e seguido e temos uma escola real (como na figura acima) com todas as suas idiossincrasias. Soma-se a isso o fato de que

os fazedores das políticas públicas educacionais - economistas, políticos, empresários, estatísticos, matemáticos, engenheiros, professores universitários, e até profissionais titulados em educação, etc. - na ausência do conhecimento técnicocientífico sobre o fato educativo, não titubeiam em fazer uso, fartamente, dos princípios, métodos e técnicas dominantes no mundo dos negócios, ignorando por completo a especificidade do trabalho escolar e a necessidade de levar em conta sua singularidade na tentativa de fazê-lo efetivo. (PARO, 2013, p. 959).

Paro (2012, 2013) comenta ainda que algumas escolas se restringem ao conteúdo, à mera transmissão dele e isso acaba por minimizar as relações que existem entre professor/a-estudante e ensinar-aprender configurando-se, muitas vezes, numa educação bancária (FREIRE, 1975) na qual o/a professor/a 'deposita' os conhecimentos nos estudantes.

Tais conhecimentos são estruturados e organizados nas mais diferentes áreas, que vão desde o idioma materno e línguas modernas estrangeiras a disciplinas relacionadas às ciências humanas, da natureza e matemática. Essas disciplinas - que compõem o currículo da educação básica, que demarcam quais conteúdos devem ser ensinados e aprendidos - acabam sendo hierarquizadas conforme seu grau de 'importância' na formação de estudantes e isso se reflete, inclusive, nas cargas horárias das disciplinas, na qual as 'mais importantes' têm uma carga horária maior e as "menos" têm uma carga horária menor. Convém elucidar, entretanto, que o objeto da ação educativa não se restringe às disciplinas, ao conteúdo e nem mesmo ao conhecimento. "Se ela tem por fim a formação de personalidades humano-históricas, seu objeto 
é a cultura em sua integralidade: conhecimentos, valores, arte, ciência, filosofia, crenças, tecnologia, direito, enfim, tudo o que é produzido historicamente" (PARO, 2013, p. 960).

E o/a professor/a tem um papel importante nesse processo de ensino-aprendizagem. Não no sentido de transmitir conhecimentos, mas no sentido de mediar, de propiciar "condições (ensino) para que o educando se aproprie (aprendizado) da cultura" (PARO, 2013, p. 960). Em Segunda Chamada, a figura do/a professor/a é construída como o pilar e herói da educação. Mas vemos no ecrã, concomitantemente, uma imagem de desvalorização seja no retorno financeiro seja em prestígio social desse/a profissional da educação, pois ainda paira no imaginário coletivo - principalmente dos políticos - que o/a professor/a não é um trabalhador/a e que não trabalha, 'apenas dá aula'. E, em decorrência disso, vemos casos de professores/as trabalhando em mais de uma escola (Sônia) e em mais de um turno (Sônia e Paulo) ou que comercializam, no ambiente escolar, produtos de beleza (Eliete), o que é proibido segundo o regimento escolar, para complementar a renda.

Esse é o cenário em que se passa a série, aqui analisada, e é nesse ambiente escolar que Marco André vai lecionar. Ele é um professor de arte, de classe média e que sempre trabalhou em escolas particulares e - por um erro da secretaria escolar - é contratado para trabalhar na Escola Estadual Carolina Maria de Jesus. Em seu primeiro dia de trabalho, ele vai até à direção se apresentar, bate à porta, que é aberta pelo diretor Jaci: “- Pois não?" "- Boa noite. Você é o diretor Jaci? Sou Marco André”. “- Oh, Marco André a gente tava esperando você. Entra. Essa é Lúcia, professora de português". "- Prazer, Marco André. Se quiser, eu posso mostrar a escola para ele”, disse Lúcia ao diretor (SEGUNDA CHAMADA, 2019).

É na companhia de Lúcia que, novamente, damos um giro pela escola. Nesse caminhar vamos conhecendo a escola que é apresentada ao professor recém-chegado e conhecendo também Marco André, que se assusta com a precariedade da infraestrutura da escola e do contato com outra realidade educacional. Passando por um corredor, Lúcia comenta que a luz deu curto circuito na semana passada. Vendo a reação do colega, ela deduz que ele nunca deu aula em uma escola pública e dá a dica para ele se preparar, pois "aqui é curto circuito todo dia. A gente tem turmas de ensino médio e turmas de ensino fundamental. Mas o grande desafio é conseguir que os alunos cheguem até o final", diz a professora. Marco André questiona se muita gente desiste e Lúcia responde que "não é todo mundo que segura o tranco. Os alunos trabalham o dia inteiro, né? Depois é que eles vêm para a escola. Difícil, alguns moram longe [...] nem sempre é fácil Marco André, mas você vai ver que vale a pena" (SEGUNDA CHAMADA, 2019).

Lúcia e Marco André se encaminham para a sala dos professores, onde ele é apresentado às professoras Eliete e Sônia e esta, muito 'espirituosa', o recebe com um sonoro 'bem-vindo ao paraíso'. Apesar do cenário, Marco André se mostra animado para o novo desafio. O giro pela escola termina na sala de aula, onde ele é apresentado aos estudantes por Lúcia, que assim o apresenta: "boa noite, gente. Vamos fazer silêncio? Eu quero apresentar pra vocês o Marco André nosso novo professor de biologia". Marco André sem entender nada, responde que "aqui eu dou aula de arte". Todos/as ficaram confusos! (SEGUNDA CHAMADA, 2019).

\section{3 "Eu vim hoje, amanhã eu não sei se eu consigo"}

O título dessa seção é a resposta de um dos estudantes, Vítor (Júlio Silvério), para a professora Lúcia em relação à frequência dele às aulas devido ao trabalho e nos ajuda a pensar as especificidades da EJA. Recorrendo aos escritos de Carolina, encontro no texto 'Favela' uma 
passagem que nos ajuda a pensar a relação entre educação, trabalho e a população pobre. Carolina escreve:

\begin{abstract}
Os filhos dos operariós não tem infancia. Não tem brinquedos. Não tem distrações e tão logo terminem os cursos primariós são obrigados a trabalhar nas fábricas, onde muito cedo perdem os sonhós tão propriós da puerícia. Muitos se esforçam para estudar, mas dessanimam e intérrompem os estudós quando sentem a penósa e embaraçosa situação, sêja pela dificuldade finançêira com que lutam. Sêja pelo grande esforço físico dispendido. O estudante não tem proteção. Não tem desconto nós livros didaticos. As taxas escolares aumentam extorsivamente. É preciso interessar pelo jovem pobre que estuda, auxiliando-o pois precisamos que garantam um futuro melhor para nóssa terra. (JESUS, 2014, p. 53).
\end{abstract}

Pelo excerto, observamos que Carolina demonstra preocupação com os jovens que, embora tenham vontade ou desejo de estudar, se veem obrigados a trabalhar para ajudar nas despesas de casa. A escritora escancara, por meio de seu texto, a desigualdade social e mostra a dificuldade de acesso à escola e a permanência nela por parte de pessoas pobres. No Brasil, infelizmente, a pobreza tem cor e os dados das desigualdades raciais apontam que "adolescentes negros são precocemente absorvidos pelo mercado de trabalho informal e se afastam do sistema de ensino regular. [Além disso,] os jovens negros são maioria entre os desempregados" (BRASIL, 2013, p. 55). Essa é uma das realidades vividas por Vitor e por inúmeros estudantes da EJA tanto na ficção quanto na realidade.

Embora haja dispositivos legais e políticas públicas que prevejam o acesso e a permanência de jovens e adultos na escola, ainda temos barreiras a serem transpostas na prática. A Lei de Diretrizes e Bases da Educação Nacional (LDB/1996), por exemplo, prevê em seus artigos a educação como direito. No que concerne à educação de jovens e adultos, lemos nos $\operatorname{artigos} 4^{\circ}, 37$ e 38 que:

\begin{abstract}
O dever do Estado com educação escolar pública será efetivado mediante a garantia de: [...] acesso público e gratuito aos ensinos fundamental e médio para todos os que não os concluíram na idade própria; [...] oferta de ensino noturno regular, adequado às condições do educando; oferta de educação escolar regular para jovens e adultos, com características e modalidades adequadas às suas necessidades e disponibilidades, garantindo-se aos que forem trabalhadores as condições de acesso e permanência na escola. [...] A educação de jovens e adultos [...] constituirá instrumento para a educação e a aprendizagem ao longo da vida. Os sistemas de ensino assegurarão gratuitamente aos jovens e aos adultos [...] oportunidades educacionais apropriadas, consideradas as características do alunado, seus interesses, condições de vida e de trabalho, mediante cursos e exames [...] A educação de jovens e adultos deverá articular-se, preferencialmente, com a educação profissional. [...] Os sistemas de ensino manterão cursos e exames supletivos, que compreenderão a base nacional comum do currículo, habilitando ao prosseguimento de estudos em caráter regular. (BRASIL, 1996).
\end{abstract}

Esse é o cenário ideal, que não necessariamente corresponde à realidade, mas que já representa um grande avanço, graças aos movimentos sociais, para a garantia do direito à educação para todas/os. Santos, Pereira e Amorim (2018, p. 124) pontuam que a "EJA, historicamente, teve como marco o engajamento nos movimentos sociais, na educação popular, e almejava a alfabetização e adultos, a humanização e conscientização dos sujeitos". Vale mencionar, ancorado em Saviani (1983, p. 193), que "a legislação constitui uma mediação entre 
a situação real e aquela que é proclamada como desejável, havendo a probabilidade de contradições e defasagens entre elas" e que a lei por si só não muda o cenário educacional nem a organização curricular.

A EJA desperta muitas reflexões, tanto que inúmeras são os/as pesquisadores/as que se debruçam sobre essa temática. Nesse sentido, os estudos sobre ela discutem questões relacionadas aos seus fundamentos históricos e políticos; aos sujeitos, às identidades do/a educador/a e do/as educandos/as da EJA e à formação de professores para a EJA; ao currículo; à avaliação, ao planejamento e às metodologias para a EJA; às perspectivas freireanas na formação docente e, dentre uma gama de temas, ao ensino de arte na EJA. Tendo esse espectro, é comum nos estudos sobre a EJA entendê-la como uma modalidade de ensino complexa voltada para pessoas que, por uma série de fatores, não tiveram a oportunidade de estudar ou continuar seus estudos na idade regulamentar, quando mais novas. Di Pierro argumenta que a EJA não tem um público único. Para ela,

nós temos dois grupos que foram precocemente excluídos dos seus direitos educativos. Um grupo de pessoas, em geral, mais idosas com idade mais avançada que viveram em uma época em que o acesso à educação era mais difícil principalmente nas zonas rurais. Então, nesse grupo nós vamos ter os analfabetos e as pessoas de muito baixa escolaridade. E há um segundo grupo muito numeroso e bastante heterogêneo de pessoas que abandonaram precocemente os seus estudos por fatores extraescolares e sociais que tem a ver com pobreza, necessidade de ingresso precoce no mercado de trabalho, mas também por fatores escolares em função do fracasso de terem tido uma trajetória escolar interrompida, malsucedida com sucessivas reprovações, que acabam desestimulando e levando ao abandono escolar. (DI PIERRO, 2014, online).

A complexidade desta modalidade se dá, dentre os motivos levantados por di Pierro, "porque envolve dimensões que transcendem a questão educacional" (STRELHOW, 2010, p. 49) e traz à tona questões de confrontação da classe social na sala de aula (HOOKS, 2019) tal como pontuou Jesus (2014), em 'Favela' e tal como podemos ver em Preciosa, que é um "retrato sem photoshop da situação cotidiana de precariedade e violência experimentada pelas mulheres negras que vivem abaixo da linha de pobreza" (COBRA, 2014, p. 9), de Sapphire, que teve como inspiração Carolina e sua obra. Em Segunda Chamada, desde o primeiro capítulo, visualizamos essa confrontação da classe social em intersecção com gênero e raça. $\mathrm{E}$ isso acaba por gerar discussões entre a comunidade escolar.

Dada a complexidade, e também por isso, a EJA possui características específicas que passam pela constituição das turmas compostas por sujeitos com inúmeras diferenças e, portanto, diversos que estão em diferentes estágios de formação escolarizada; pela preparação das/dos professoras/es para lidar com essas diferenças e diversidade; pelas políticas e vontade política da gestão escolar e dos sistemas de ensino; pelas adequações curriculares, no intuito de aproveitar e fazer uso dos saberes cotidianos dessas pessoas nos processos de ensino e de aprendizagem.

Existem inúmeros perfis de professores. Na série, vemos professores preocupados cada um à sua maneira - com o desenvolvimento do corpo discente no intuito de formarem cidadãos. Em uma discussão entre o diretor e Lúcia, visualizamos essa preocupação. Jaci comenta que a evasão no ensino noturno é normal e que isso não é problema nem dela nem dele, mas Lúcia discorda: "Eles podem desistir da escola, eu não desisto deles (SEGUNDA CHAMADA, 2019). A evasão é uma constante na EJA. A diversidade de sujeitos na EJA, uma vez que ela atende estudantes (que possuem inúmeros marcadores sociais) do ensino 


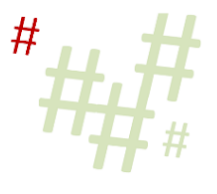

fundamental (em processos de alfabetização) ao ensino médio (comumente integrado a um curso profissionalizante) é um dos maiores desafios dessa modalidade. "Seu público prioritário inclui desde os idosos da zona rural aos jovens das grandes cidades, as minorias étnico-raciais, pessoas com deficiência e a população privada de liberdade" (IPM, 2013, online). Esse é, em maior ou menor proporção, o perfil dos/as estudantes retratados na série.

Em cena, vemos um mosaico de sujeitos composto por pessoas que facilmente encontraríamos no nosso convívio social. É o caso de Jurema da Costa (Teca Pereira), uma senhora de 71 anos que após ter criado os filhos e cuidado do marido decide estudar e fazer isso por ela e para ela. Ao ir para as aulas, Jurema dizia ao marido que ia à igreja, mas ele acabou descobrindo e foi buscá-la na escola gerando constrangimento público. Para ele, lugar de mulher é em casa, cuidando do marido e dos filhos, que ela já estava velha para estudar e estudar para quê? "Pra ser melhor que eu? Ou eu ou a escola [disse ele. Ela respondeu:] não tá tarde. Eu ainda tenho tempo. Eu passei minha vida toda cuidando de vocês. É nessa escola que pela primeira vez eu tô fazendo alguma coisa por mim. Se você me ama, você tem que entender" (SEGUNDA CHAMADA, 2019).

Sabemos que não tem idade certa para estudar, para sair da ignorância e esse conjunto de falas corrobora os dados pontuados por Paiva (2014) e Soares (2014) quando discutem os desafios da EJA. Soares pontua que, no caso das mulheres de maior idade, um dos motivos pelos quais elas abandonaram a escola é o machismo, seja porque os pais não queriam que elas escrevessem 'bilhetinhos para os namorados', seja porque depois de casadas já tinham cumprido sua função social. Paiva argumenta que a educação é um direito social tardiamente conquistado pela cidadania brasileira na Constituição Federal de 1988. Nesse sentido, além do que pontua di Pierro (2014) sobre o público da EJA, o grupo com mais idade também vem de uma interdição ao direito à escola e é nas faixas de maior idade que nós vamos encontrar as mulheres com menos escolaridade (PAIVA, 2014, online).

Também compõem esse mosaico as personagens Sílvio Oliveira, 68 anos, que vive em situação de rua, mas nem por isso falta às aulas; Pedro (Vinícius de Oliveira) e Márcia Soares (Sara Antunes), 34 e 30 anos, respectivamente, um casal protestante que quer dar orgulho à filha que nasceu na escola; Alejandra (Rosalva Vanessa) e Javier Barrios (Gabriel Díaz), 26 e 24 anos, irmãos venezuelanos que vieram para o Brasil na tentativa de uma vida melhor; Vitor (Júlio Silvério) e Gislaine de Oliveira (Mariana Nunes), garoto e garota que fazem programas sexuais; Gedivan Lima, o Giraia (José Trassi), 34 anos, que vende remédios de tarja preta sem receita na escola; Aline Fernandes (Ingrid Gaigher), 28 anos, e Joelma Barbosa (Ariane Souza), 30 anos, colegas que vendem salgados no pátio da escola; Valquíria Almeida (Georgette Fadel), 45 anos, estudante que está em condicional e trabalha vendendo itens de beleza; Cleiton da Silva (William da Costa), 19 anos, jovem que é acompanhado na escola pela mãe para que não entre em facções criminosas como aconteceu com seu irmão; Rita Maria de Cássia (Nanda Costa), dona de casa, mãe de três filhos; Natasha dos Santos (Linn da Quebrada), 29 anos, cobradora de ônibus que sofre agressões na escola e fora dela por não ser uma mulher cis; Maicon Douglas Pereira (Felipe Simas), motoboy que sonhava em ser professor, dentre outras personagens que poderiam ser reais e nossos/as vizinhos/as.

Muitos são os motivos que levam essas pessoas à escola e aos estudos. A narrativa da série e a literatura especializada nos dão algumas pistas do porquê disso. Essas pessoas, que geralmente trabalharam o dia todo, se juntam à noite, na escola, no intuito de, por meio da educação, ascender socialmente. Outro motivo, que aqui pode ser mencionado, é a satisfação pessoal e a conquista de um direito fundamental que é a educação por parte dessas pessoas. Mas há também, enquanto estímulo ou pressão, as "exigências econômicas, tecnológicas e competitividade do mercado de trabalho" (STRELHOW, 2010, p. 250). 


\section{4 "Aqui eu dou aulas de arte!"}

Foi o que respondeu Marco André ao ser apresentado como professor de biologia. Nesta seção, intentou-se analisar a representação da personagem Marco André, professor de arte, com vistas à reflexão e discussão do ensino de arte na EJA. Candido e Feres Júnior (2019, p. 2) pontuam que a "análise de representações é um terreno pantanoso", eu diria movediço, pois a palavra e a ideia de representação possuem inúmeras acepções, que vão desde a delegação de poder como eleger um/a representante, por exemplo, à produção de imagens e imaginários. Além disso, a representação "inclui práticas de significação e os sistemas por meio dos quais os significados são produzidos, posicionando-nos como sujeitos" (FERREIRA, 2014, p. 217). É nesta perspectiva que este artigo se ancora, pois quando nos debruçamos sobre produtos culturais audiovisuais e cinematográficos temos que levar em consideração que eles são

instâncias produtoras de sentido, capazes de criar e consolidar determinadas narrativas, imagens e visões de mundo, em detrimento de outros; e também de instituir valores e representações impor novos significados, condutas e afetos, que incidem como normas e regimes de verdades nos processos de subjetivação dos indivíduos. (FERREIRA; SOUZA, 2015, p. 02).

Nesse sentido e considerando que, na contemporaneidade, o audiovisual tem desempenhado a função de contador de histórias (LUZ, 2002; FERREIRA; SOUZA, 2015) a representação de Marco André será aqui analisada a partir das cenas em que ele protagoniza e que sejam possíveis estabelecer conexões com o ensino de arte. Após sua apresentação aos estudantes, Marco André e Lúcia (Figura 04) foram à diretoria para resolverem a confusão. Na diretoria, visualizamos uma cena que diz muito sobre o lugar da arte na escola em tela e que serve para pensarmos a arte nas escolas públicas de um modo geral.

Figura 04 - Vocês têm professor de arte aqui?

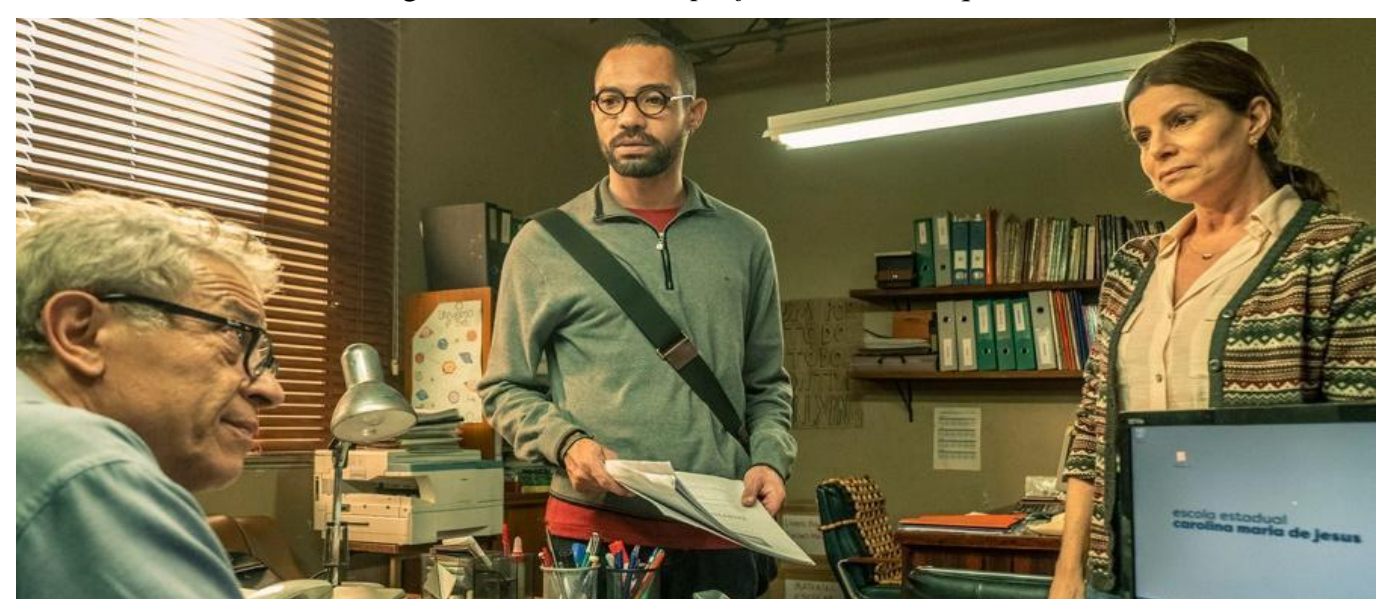

Foto: Mauricio Fidalgo, O Globo (2019).

[Lúcia] Você confundiu arte com biologia, Jaci? [Jaci] Não, não, não. Não é culpa minha não. Foi alguma confusão na secretaria. [Marco André] Desculpa, mas vocês têm professor de arte aqui? [Jaci] Ah meu querido, no momento arte não está na nossa lista de prioridade. [Lúcia] Ah, mas devia estar. [Marco André] Eu tô disposto a ficar. [Lúcia] Olha aí, você é dos meus. [Jaci] Lúcia, você não tem uma aula pra dar? [Lúcia] Foi um prazer te conhecer, viu Marco André? O nosso diretor é muito sensível. Tenho certeza que ele sabe como é difícil encontrar um professor de arte. (SEGUNDA CHAMADA, 2019). 
A fala do diretor da escola elucida o lugar destinado ao ensino de arte que, neste caso, não é prioritário na formação dos/das estudantes enquanto sujeitos críticos, mesmo sendo uma disciplina obrigatória. Embora o ensino de arte formal esteja presente no Brasil desde o século XIX, ainda hoje temos escolas que não possuem o ensino de arte estruturado e/ou há ausência de professores da área específica e qualificados para o exercício da docência. Na EJA, por vezes, alguns professores de outras áreas lecionam arte nessa modalidade no intuito de complementar sua carga horária. A fala de Lúcia, a respeito de como é difícil encontrar um professor de arte, vai ao encontro da realidade educacional no Brasil, que apesar de avançar na formação de professores licenciados em arte (artes visuais, dança, música e teatro, para citar algumas linguagens) ainda não atende a todos os municípios brasileiros.

De modo geral - para efeito de contextualização - a arte passou a ser disciplina em toda a educação básica desde a Lei de Diretrizes e Bases para o Ensino de $1^{\circ}$ e $2^{\circ}$ graus de 1971 (LDB/1971). Em 1996, ela passa a ser obrigatória, conforme lemos no segundo parágrafo do Artigo 26, da LDB/1996, que o ensino da arte, especialmente em suas expressões regionais, constituirá componente curricular obrigatório da educação básica e no segundo parágrafo do Artigo 35-A, também da LDB/1996, lemos que a Base Nacional Comum Curricular (BNCC) referente ao ensino médio incluirá obrigatoriamente estudos e práticas de educação física, arte, sociologia e filosofia (BRASIL, 1996).

Contudo, reiterando o já exposto, a legislação por si só não efetiva o ensino de arte na educação básica. Tal efetivação dependerá de inúmeras ações que envolvem tanto a comunidade escolar nas mudanças curriculares quanto a sociedade e as instituições formadoras de licenciados/as em artes visuais, dança, música e teatro que atuarão na educação básica e propiciarão aos estudantes "uma compreensão crítica das diferentes culturas e expressões artísticas, a valorização da herança cultural da sociedade brasileira e o acesso democrático aos conhecimentos artísticos produzidos pela humanidade" (ALVARENGA; SILVA, 2018, p. 1026). Nesse sentido, a arte mesmo sendo uma área do conhecimento obrigatória, "vem sendo deixada de lado na educação básica, quando é concebida, ainda em algumas escolas, como 'atividade' ou 'saber subsidiário"” (ARAÚJO, 2014, p. 16). Se compararmos a sua carga horária, tanto na EJA quanto no ensino regular e na educação profissional integrada, com as de outras disciplinas notaremos que ela é bem reduzida e isso dificulta as relações e os processos de ensino-aprendizagem.

Voltando à narrativa de Segunda Chamada, Jaci pede desculpas a Marco André pelo transtorno enquanto se dirigem à saída da escola. Marco André insiste em sua permanência no quadro de professores e quando eles chegam na entrada da escola percebem que o carro do professor tinha sido roubado. Enquanto Jaci faz alguns telefonemas na tentativa de reaver o carro, Marco André caminha pela escola e observa o espaço. Ele para diante de uma parede e a contempla. Sônia, a professora de história, vai ao seu encontro e os dois conversam: 
Figura 05 - Enquanto houver repressão haverá resistência

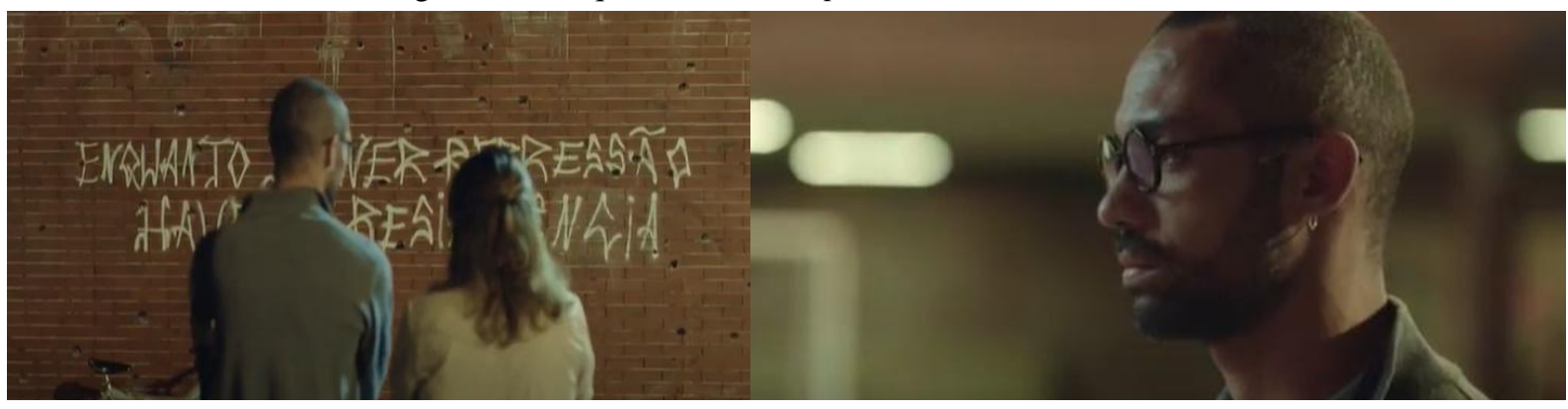

Fonte: Frames extraídos de Segunda Chamada (2019)

[Sônia] Isso foi no último tiroteio. Essa parede virou peneira. [Marco André] Tava lendo o grafite. [Sônia] Tô a tanto tempo nessa escola que nem consigo ver mais o que está na minha frente. [Marco André] Você tá falando do seu aluno? [Sônia] Como é que faz pra dar aula agora? [Marco André] Ele já foi socorrido. Tá tudo bem. [Sônia] Verdade. Quem não tá bem sou eu. [Marco André] Somos dois. Pediram um professor de biologia, mas eu dou aula é de arte. [Sônia] Nossa, que sorte. Aproveita pra fugir desse lugar. [Marco André] Meu carro foi roubado. Agora eu não sei como sai daqui. [Sônia] Nem eu, tô tentando há dez anos e não consigo [...] Vem cá, você com a condição que tinha porque escolheu esse fim de mundo pra dar aula, hein? [Marco André] É um assunto delicado [...] outro dia eu te conto melhor essa história. (SEGUNDA CHAMADA, 2019).

Às vezes estamos tão cômodos ou tão expostos às violências, que perdermos a capacidade de olhar. Enquanto Sônia via furos provocados por tiros, Marco André via um grafite com os dizeres: "enquanto houver repressão haverá resistência" (Figura 05). Existia um forte motivo pessoal para Marco André querer trabalhar naquela escola. Ele nasceu em um hospital perto dali e foi entregue para adoção. Ele queria, de alguma forma, contribuir com a comunidade. Depois de um tempo, Jaci reaparece e dá um conselho a Marco André: "Vem de ônibus, amanhã...". "Amanhã?". "Você não disse que queria ficar? Já mudou de ideia? Desistiu?". "Jaci, se eu me atrasar a culpa é da condução" (SEGUNDA CHAMADA, 2019).

No segundo dia de trabalho de Marco André, vemos ele e Eliete conversando pelos corredores enquanto se encaminham para as salas de aula.

[Eliete] Eu tô achando o máximo ter aula de arte aqui. Os alunos vão pirar com essa ideia. Mas como é que é? Porque na minha época era pintura, colagens... [Marco André] Eu sou formado em Educação Artística, mas eu dou aula de teatro. [Eliete] Olha, eu sou atriz um pouco. [Marco André] Ah, é? [Eliete] Eu sou um pouco atriz. Acho que todo professor é um pouco performático, né? Pra vender minhas coisinhas eu uso de interpretação... [Marco André] Isso é verdade. [Eliete] Olha, tá entregue. Qualquer coisa grita, tô aqui. Boa sorte. [Marco André] Tranquilo Eliete, não é a primeira vez que eu dou aula. [Eliete] É, mas é a sua primeira vez no ensino noturno. Guarda a minha boa sorte aí no bolso. (SEGUNDA CHAMADA, 2019).

Marco André saiu de uma conversa animada e receptiva com a colega de trabalho para entrar em uma sala de aula em que os/as estudantes nem o viram chegar. Ele tenta começar a aula algumas vezes, mas tem sua voz encoberta pelas conversas paralelas. Uma das estudantes tenta ajudá-lo e pede silêncio à turma, "ô gente! Deixa o professor dar aula", mas sem sucesso. Marco André anda pela sala pedindo silêncio e que os/as estudantes sentem para dar início à aula. Um dos estudantes não gostou de ser chamado atenção em público e isso gerou um clima 
indesejado para a aula e para um primeiro dia de trabalho. Na sala dos professores, em uma conversa com Sônia, Marco André relata o ocorrido e ela lhe diz que ele não pode desrespeitar um aluno 'pai de família' na frente dos outros. Nesses casos, segundo ela, é melhor tacar o apagador no quadro com vontade. Dessa forma os/as estudantes entendem o recado e o 'esporro' é geral. Após o intervalo, Marco André tenta novamente dar aula. Vendo que não conseguiria, resolveu utilizar a dica do apagador (Figura 06) e, enfim, ter a atenção dos/as estudantes.

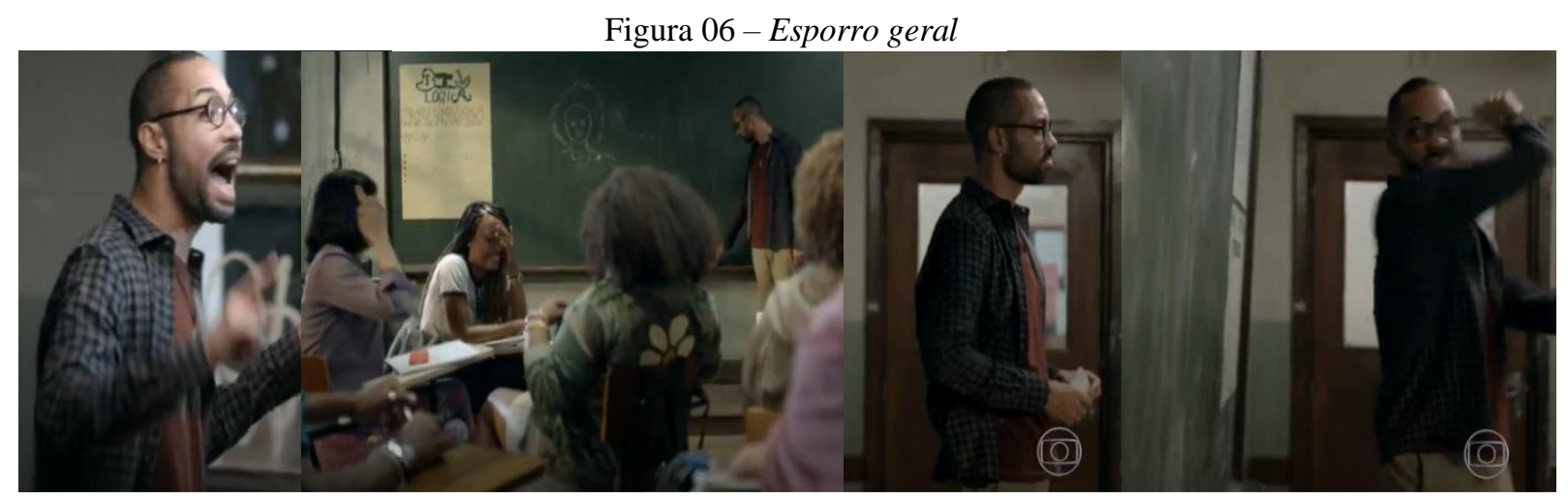

Fonte: Frames extraídos de Segunda Chamada (2019)

Marco André continua a aula, mas depois que ela termina, ele reflete sobre o andamento dela. Eliete, que tinha desejado sorte a ele, o encontra no terraço da escola. "O que houve artista? Que cara é essa?"

[Marco André] Taquei o apagador no quadro pra poder dar aula. [Eliete] Funcionou? [Marco André] Achei que tava dando aula num colégio de adultos. [Eliete] É, é tudo criança grande. Tem gente que me pede visto no caderno porque nunca veio pra escola antes, você acredita nisso? [Marco André] Eliete, eu não quero ficar tacando apagador no quadro todo dia. Eu sou um professor de arte. Eu sou completamente contra esse tipo de coisa... [Eliete] Então eu tenho que te avisar que o apagador vai ser o menor dos seus problemas aqui. [Marco André] Não sei se eu sou o professor adequado para esses alunos. [Eliete] Claro que é. É sim. Questão de quilometragem só, vai por mim. [Marco André] Tô meio perdido... [Eliete] Ah, não vai desistir não, hein? Apostei cinquenta reais com a Sônia que você ia aguentar. Sexta-feira eu tenho pagode e tô dura. Se vira! Anima! (SEGUNDA CHAMADA, 2019).

Com isso, vemos que na escola, na EJA e no ensino de arte são necessárias negociações para um bom andamento das aulas e que, no processo da ação educativa, surgem questionamentos por parte do docente se ele realmente é adequado para aqueles/as estudantes e se suas ações são oportunas. Temos nos cursos de licenciaturas uma série de disciplinas de cariz pedagógico no currículo, mas elas são voltadas para os/as estudantes ideais ou reais?

Saímos do apagador no quadro negro para O Pagador de Promessas. O episódio discutia o tema da intolerância religiosa. Era uma noite chuvosa, quando Marco André tem sua aula interrompida (Figura 07) pelo diretor Jaci, acompanhado pela professora Sônia. 


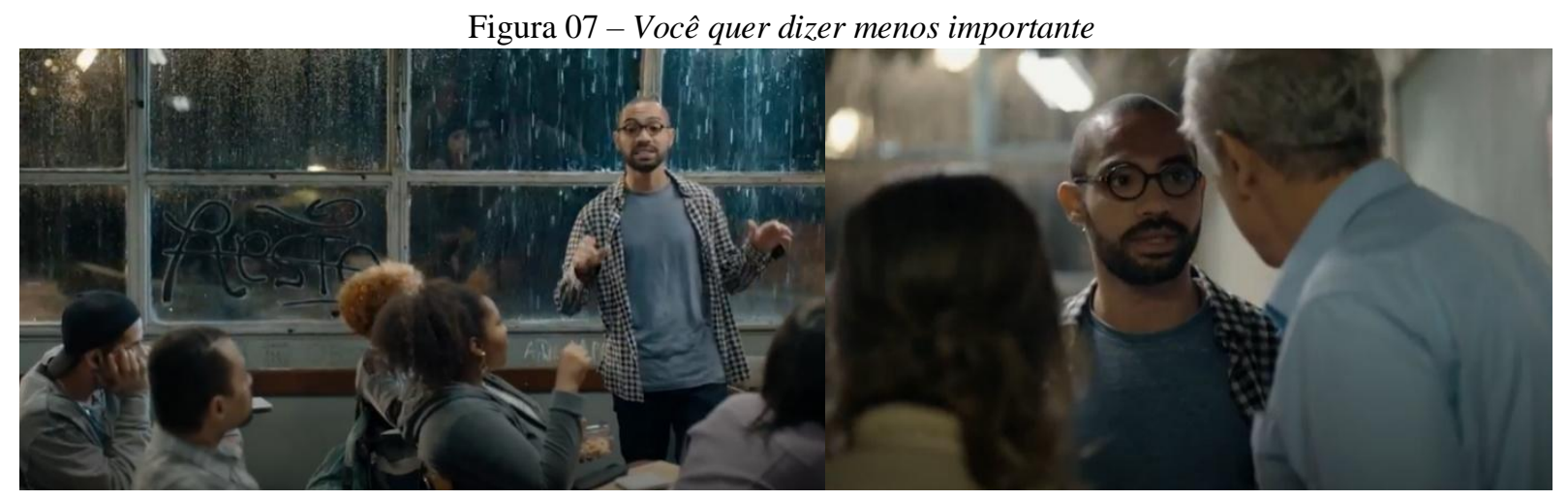

Fonte: Frames extraídos de Segunda Chamada (2019)

do Burro carrega uma cruz nas costas e com sua mulher Rosa caminham sete léguas do sertão baiano até Salvador para pagar uma promessa. Essa obra de Dias Gomes foi adaptada pro cinema pelo cineasta... [Jaci interrompe a aula e pede para conversar com Marco André, que diz:] olha gente, calma que a saga do Zé do Burro ainda nem começou, hein? [Todos riem]. [Jaci] Marco André, a sala da Sônia tá cheia de goteiras, o chão tá todo alagado... você não se importaria de ceder a sua sala para a aula de história, né? [Marco André] Sim, mas eu vou dar aula aonde? [Jaci] Ela tem um conteúdo curricular para cumprir. Arte me parece mais flexível... [Marco André] Você quer dizer menos importante, no caso. [Jaci] Essa é a solução que vai causar menos prejuízo para todo mundo. Marco André, eu conto com a sua colaboração. [Marco André] Ok pessoal, então a gente continua com O Pagador de Promessas na semana que vem. Tivemos um problema. Quem puder assistir ao filme vai ajudar no conteúdo da próxima aula, hein? [SEGUNDA CHAMADA, 2019].

Novamente, vemos, na fala do diretor, a arte como uma disciplina não prioritária ou que é lida pela ótica da brincadeira, do descanso e/ou flexível, sem conteúdo curricular e que pode ser suprimida da vivência dos/as estudantes. Todavia, a arte na educação como expressão pessoal e cultura é, segundo Barbosa,

um importante instrumento para a identificação cultural e o desenvolvimento individual. Através da arte é possível desenvolver a percepção e a imaginação, apreender a realidade do meio ambiente, desenvolver a capacidade crítica, permitindo analisar a realidade percebida e desenvolver a criatividade de maneira a mudar a realidade que foi analisada. (BARBOSA, 2000, p. 9).

Dessa forma, a arte contribui, dentre uma gama de coisas, para incitar o pensamento e 'ensiná-la' é uma forma de possibilitar experiências e vivências significativas em apreciação, reflexão e elaboração artística e, nesse sentido, é necessário que ela esteja presente também na escola e no ensino. Sônia foi conversar com Marco André para dizer que não concorda com a atitude do diretor. "Tudo bem Sônia, eu já entendi. Arte não é prioridade. Não tem lugar nessa escola", responde Marco André. Diante da situação, Sônia se lembra de um lugar na escola onde Marco André poderia dar suas aulas. Ela avisa que o lugar, que é utilizado como depósito, está muito tempo fechado e cheio de poeira, mas Marco André não se importa com isso, tudo o que ele quer é dar aula de arte. Sônia liga a luz e constata que o lugar está pior do que ela imaginava. Marco André está maravilhado com o espaço e percebemos isso pelo enquadramento da câmera que gira em torno dele (Figura 08). "Sônia, isso aqui é um teatro. Olha o pé direito desse lugar! Gente, como é que deixa um lugar desses ficar assim?", diz o professor. Ele a agradece e ela retorna à aula. 
Figura 08 - Só quero poder dar a minha aula - a descoberta do teatro

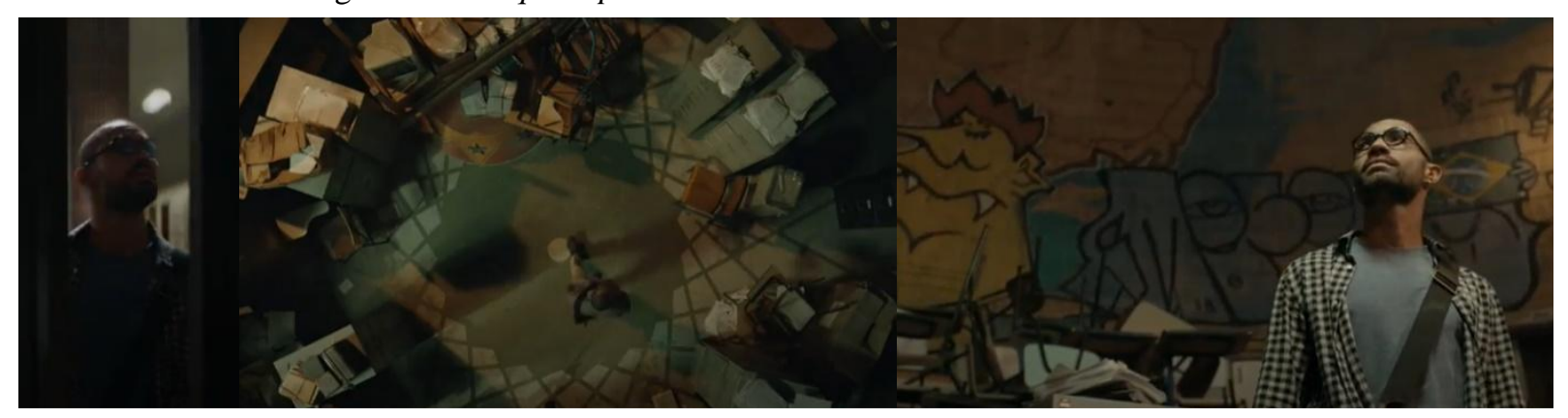

Fonte: Frames extraídos de Segunda Chamada (2019)

O professor faz um mutirão com os/as estudantes para limpar e organizar o teatro, a mais 'nova' sala de aula. Sônia, que não consegue terminar a aula de história devido às goteiras na sala (Figura 03), se junta ao mutirão com mais estudantes para ajudar. Enquanto limpavam e organizavam o teatro, Jaci aparece:

\begin{abstract}
[Jaci] Mas o que é que tá acontecendo? Que zona é essa no depósito? [Marco André] Depósito não. Isso aqui é um teatro. [Jaci] Está desativado há muito tempo... [Sônia] É, mas é o único lugar que tá sem goteira na escola, né Jaci? [Jaci] Por isso mesmo é que todos os arquivos da escola estão guardados aqui, Sônia. [Marco André] Sim, Jaci, mas agora com as aulas de arte a gente pode voltar a usar esse espaço como teatro. [Estudantes] É! [Jaci] É melhor vocês voltarem as coisas pro lugar que estavam antes [Sônia] E os alunos vão ter aulas onde? [Jaci] Se não tiver um lugar pra dar aula, manda os alunos pra casa. Não façam mais uma coisa dessas sem falar comigo antes. (SEGUNDA CHAMADA, 2019).
\end{abstract}

Os/as estudantes perguntam o que devem fazer. Sônia responde que deveriam fazer o que o diretor falou. Mas, apesar da negativa de Jaci em relação ao uso do espaço, os/as estudantes resistem e continuam limpando o teatro. Com o teatro minimamente organizado, Marco André e Sônia dão prosseguimento às suas aulas (Figura 09), que não era apenas de arte ou só de história, mas de uma convergência entre as duas, de modo interdisciplinar.

Figura 09 - Arte e História - convergências

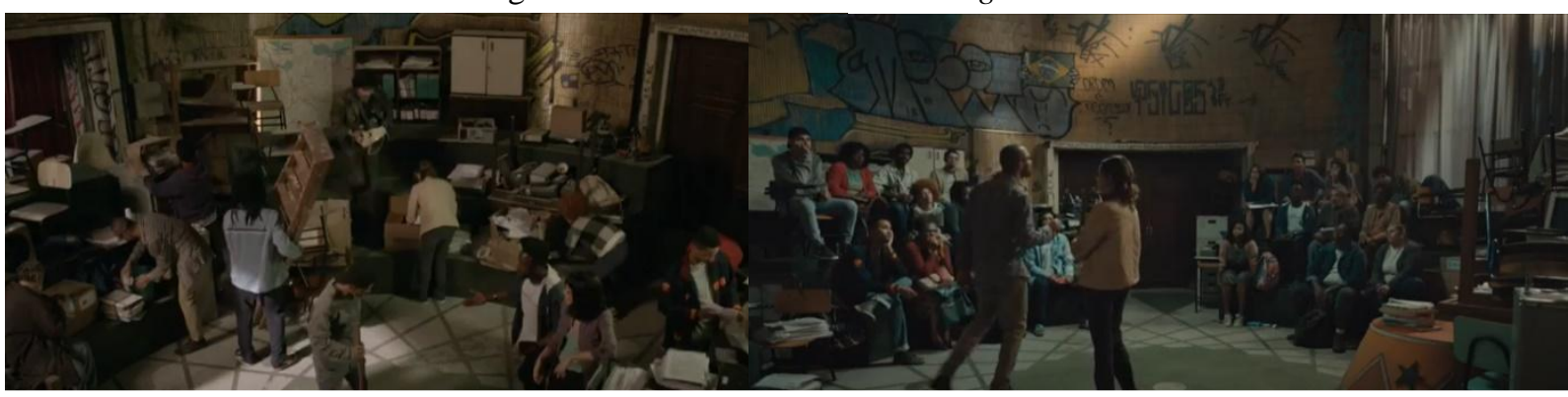

Fonte: Frames extraídos de Segunda Chamada (2019)

[Marco André] O Pagador de Promessas fala sobre a intolerância religiosa. De um lado temos um homem que quer pagar uma promessa feita no terreiro de candomblé pra Iansã... [uma estudante] Eparrey, Iansã! [Marco André] Do outro, um padre que não permite que essa promessa seja paga dentro da Igreja Católica. [Sônia] Historicamente, os [povos que foram escravizados] não podiam assumir a sua 
religiosidade. Então o que que eles faziam? Eles associavam os deuses africanos aos santos católicos. Isso é o que chamamos de sincretismo religioso. É muito comum na cultura brasileira, tá? [Marco André] Por que que a gente tá falando isso? Toda vez que a gente pensa... [Jaci interrompe a aula, mais uma vez] Marco André, eu vou precisar da sala. [Sônia] O que houve? [Jaci] A Márcia tá parindo! (SEGUNDA CHAMADA, 2019).

Renasce, metaforicamente, o teatro na escola e nele nasce a filha de um casal de estudantes. Foi preciso uma chuva e a precariedade da infraestrutura da escola para o teatro ser reaberto, mesmo a contragosto do diretor. No mutirão realizado para limpar e organizar o teatro, Marco André encontrou um porta-retrato com uma foto dos professores da escola com pouco mais de dez anos. Ele pega esse quadro e coloca em um lugar de destaque anteriormente ocupado por uma imagem de uma santa que uma estudante quebrou por não estar de acordo com o seu credo. Eliete sugere a Marco André que ele coloque uma foto $3 \times 4$ dele para complementar o quadro dos professores. Marco André comenta com Sônia e Eliete que "até que a troca foi boa. Tiraram uma santa..." "e ficaram os verdadeiros santos", complementa Eliete e Sônia lembra que "nem tão santos assim” (SEGUNDA CHAMADA, 2019).

No teatro e com o teatro (o espaço para realização da ação educativa é muito importante para os processos de ensino-aprendizagem), os/as estudantes passaram a ter nas aulas de arte a oportunidade de acessarem suas experiências e vivências de maneira artística e que se expandiram para diferentes áreas do conhecimento. Em uma das aulas, Maicon Douglas relata ao grupo uma experiência que teve no trabalho:

o elevador de serviço tinha dado B.O. aí o porteiro mandou eu subir 22 andares de escada. 22 andares carregando pizza e refrigerante pra madame jantar. Custava porra nenhuma ele ter deixado eu subir de elevador social. Tem mais, tá ligado aquele dia que eu fui parar no hospital, que eu tive um piripaque aqui? Então, o médico mandou eu ficar três dias em casa. Só que eu cheguei lá na empresa de novo, atestado e tudo na mão, já tinha outro no meu lugar. Minha história é essa aí professor: desempregado, com filho pequeno pra criar... tem pra onde correr não. (SEGUNDA CHAMADA, 2019).

Esse relato foi trabalhado pelo professor como uma possibilidade de narrativa teatral e ele propôs aos/às estudantes um exercício de encenar o que Maicon acabara de falar. No processo de montagem Silvio perguntou se podia fazer a personagem Maicon e Rita pediu para fazer a personagem do porteiro. Maicon Douglas, o próprio, insinuou que Silvio, por ser um senhor, não conseguiria subir 22 andares e que Rita não poderia ser o porteiro, pois este era homem. Rita, prontamente, o respondeu dizendo que "no teatro a gente pode tudo, né?" (SEGUNDA CHAMADA, 2019).

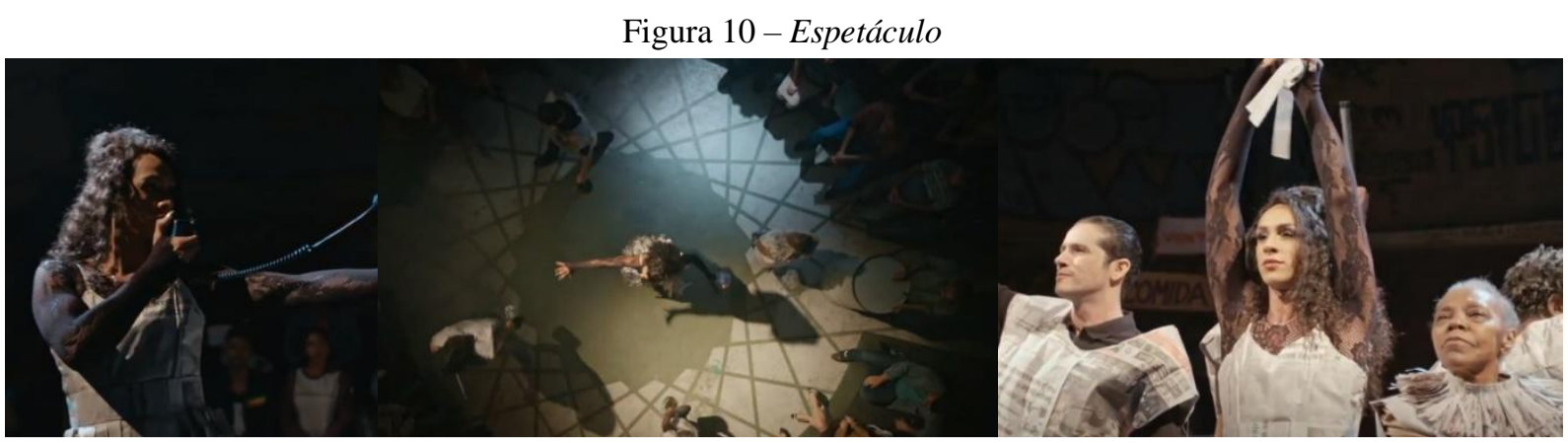

Fonte: Frames extraídos de Segunda Chamada (2019) 
Esses exercícios de encenação resultaram em um espetáculo (Figura 10), que foi apresentado à comunidade escolar. Ele foi concebido, montado, ensaiado e encenado pelo/as estudantes com orientação/direção do professor Marco André e mostra que a dramaturgia e, portanto, uma das linguagens artísticas, pode estar ligada à realidade dos/das estudantes e às suas experiências e vivências. Mais que isso, evidencia que ao entrarem em contato, refletirem e fazerem arte eles e elas percorrem trajetos de aprendizagem que lhes propiciam conhecimentos sobre suas próprias relações com a arte, consigo e com o mundo.

\section{E vamos terminar...}

Este trabalho teve como escopo analisar a representação da personagem Marco André, professor de arte, em Segunda Chamada, com vistas à problematização do lugar e do ensino da/de arte na educação de jovens e adultos da série supracitada. Para isso, se fez necessário buscar o entendimento do que vem a ser a instituição escolar, que nem sempre é receptiva, nem sempre tem as melhores infraestruturas, mas que se abriu para as diferenças e que, embora não garanta o futuro de quem por ela passe, oferta a possibilidade de escolha e um vislumbre de que as coisas podem ser diferentes por meio da educação. Se a educação básica regular e a educação profissional e tecnológica são complexas, a educação de jovens e adultos potencializa essa complexidade, pois traz uma série de questões que transbordam o perímetro escolar.

O percurso e a representação de Marco André na série nos possibilitaram observar que a arte não tinha lugar na Escola Estadual Carolina Maria de Jesus. Ela não era ensinada nem incentivada e teve que conquistar paulatinamente (pelo esforço do professor e sem apoio direto da gestão) espaço, seja no convívio com os/as estudantes, seja um espaço físico onde o professor pudesse trabalhar. Diante da análise da série, observou-se que o êxito do ensino-aprendizagem de arte ocorreu, além do esforço pessoal do professor, pelo apoio dos pares, ou seja, das outras professoras para que Marco André conseguisse se ambientar na escola, ser aceito pelos/as estudantes e realizar seu trabalho.

Além disso, nota-se que, apesar das especificidades da EJA e, talvez justamente por isso, o ensino de arte se mostrou necessário e até imperativo na ação educativa a qual visa a formação de sujeitos que apreciam, refletem e elaboram artisticamente suas realidades, inclusive. Nota-se, no decorrer dos episódios da série que, após as aulas de arte, os/as estudantes se mostraram mais engajados e críticos diante de suas realidades, e mais que palavras ou conteúdos, eles e elas estavam lendo o mundo.

\section{Referências}

ALMEIDA, Silvio. História da discriminação racial na educação brasileira - Silvio Almeida. Escola da Vila. Disponível em: https://youtu.be/gwMRRVPIYw. Acesso em: 21 nov. 2018.

ALMEIDA, Silvio. O Brasil é um país que naturalizou a desigualdade. CNN Nosso mundo. Disponível em: https://youtu.be/ZTR1MFqyTy8. Acesso em: 21 nov. 2020.

ALVARENGA, Valéria; SILVA, Maria Cristina. Formação docente em arte. Educação \& Realidade, Porto Alegre, v. 43, n. 3, p. 1009-1030, jul./set. 2018. 
ARAÚJO, Gustavo. O ensino de artes na educação de jovens e adultos. 2014. $203 \mathrm{f}$.

Dissertação (Mestrado em Educação) - Universidade Federal do Mato Grosso, Cuiabá, 2014.

BARBOSA, Ana Mae. Arte na educação para todos. In. CONGRESSO NACIONAL DE ARTE-EDUCAÇÃO NA ESCOLA PARA TODOS E FESTIVAL NACIONAL DE ARTE SEM BARREIRAS, 5. e 6., 2000, Brasília. Anais [...]. Brasília, 2000.

BILAC, Jô. Conselho de classe. 2. ed. Rio de Janeiro: Cobogó, 2016.

BRASIL. Lei 5.682, de 11 de agosto de 1971. Fixa diretrizes e bases para o ensino de $1^{\circ}$ e $2^{\circ}$ graus, e dá outras providências. Brasília, 1971.

BRASIL. Lei no 9.394, de 20 de dezembro de 1996. Lei de Diretrizes e Bases da Educação Nacional. Brasília: MEC, 1996.

BRASIL. Plano nacional de implementação das diretrizes curriculares nacionais para educação das relações étnico-raciais e para o ensino de história e cultura afro-brasileira e africana. Ministério da Educação, Secretaria de Educação Continuada, alfabetização, Diversidade e Inclusão. Brasília: MEC, SECADI, 2013.

CANDIDO, Marcia; FERES JÚNIOR, João. Representação e estereótipos de mulheres negras no cinema brasileiro. Revista Estudos Feministas, Florianópolis, v. 27, n. 2, p. 1-14, 2019.

CASETTI, Francesco; DI CHIO, Federico. Cómo analizar un film. Barcelona: Ediciones Paidós, 1996.

CASTORIADIS, Cornelius. A instituição imaginária da sociedade. Rio de Janeiro: Paz e Terra, 1982.

COBRA, Hilton. Carolina Maria de Jesus, uma escritora atlântica. In. JESUS, Carolina Maria. Onde estaes Felicidade? São Paulo: Me Parió Revolução, 2014.

CUNHA, Eneida Leal. Estampas do imaginário. Belo Horizonte: EdUFMG, 2006.

DI PIERRO, Maria Clara. Os desafios da educação de jovens e adultos. Roda de Conversa, programa veiculado pela Rede Minas no dia 29/03/2014. Disponível em:

https://www.youtube.com/watch?v=vOyWBZuMHBQ\&t=181s. Acesso em: 14 nov. 2020.

ESCOSTEGUY, Ana Carolina et. al. Notas para (re)ver as relações entre o feminino e o masculino nos longa-metragens de Jorge Furtado. Intexto, Porto Alegre, v. 2, n. 17, p. 1-13, jul.-dez. 2007.

FERREIRA, Ceiça. Uma representação de si para o mundo. Razón Y Palabra, Quito, Ecuador, n. 87, p. 216-217, jul.-set. 2014.

FERREIRA, Ceiça; SOUZA, Edileuza. Mídia, estereótipo e representação das minorias. Razón Y Palabra, [s.1], n. 88, dic. 2014 - feb. 2015. 
FERREIRA, Judivan Alves. Performances transgressoras e transviadas: narrativas audiovisuais sobre a transexualidade na escola. Revista Espaço e Tempo Midiáticos. Palmas, UFT, v. 1, n.1, p. 108-128, jan. 2017.

FREIRE, Paulo. Pedagogia do oprimido. 2. ed. Rio de Janeiro: Paz e Terra, 1975.

GIANNINI, Alessandro. 'Segunda Chamada'. O Globo. 2019. Disponível em: https://oglobo.globo.com/cultura/segunda-chamada-educacao-o-foco-central-de-nova-serieda-globo-23949573. Acesso em: 15 set. 2020.

GONZAGUINHA. Comportamento geral. 1973. Disponível em: httpps://youtu.be/ESS3jN0nKM. Acesso em: 20 nov. 2020.

GUIMARÃES, Geny. Até onde Carolina nos leva com o seu pensamento? Ao poder. In. JESUS, Carolina Maria. Onde estaes Felicidade? São Paulo: Me Parió Revolução, 2014.

HAN, Byung-Chul. Sociedade do cansaço. Petrópolis: Vozes, 2015.

HOOKS, bell. Ensinando a transgredir. 2. ed. São Paulo: Martins Fontes, 2019.

INSTITUTO PAULO MONTENEGRO (IPM). Panorama da EJA no Brasil. Observatório do Plano Nacional de Educação. 2013.

JESUS, Carolina Maria de. Onde estaes Felicidade? São Paulo: Me Parió Revolução, 2014.

LOURO, Guacira Lopes. Gênero, sexualidade e educação. Petrópolis, RJ: Vozes, 1997.

LUZ, Roberto. Filme e Subjetividade. Rio de Janeiro, 2002.

MOTTA, Luiz Gonzaga Por que estudar narrativas? In: MOTA, Célia Ladeira; MOTTA, Luiz Gonzaga; CUNHA, Maria Jandira (orgs.). Narrativas midiáticas. Florianópolis: Insular, 2012.

PAIVA, Jane. Os desafios da educação de jovens e adultos. Roda de Conversa, programa veiculado pela Rede Minas no dia 29/03/2014. (entrevista, 19':02"). Disponível em: https://www.youtube.com/watch?v=vOyWBZuMHBQ\&t=181s. Acesso em: 14 nov. 2020.

PARO, Vitor Henrique. A qualidade da escola pública. In. OLIVEIRA, Marcus; VIANA, Fabiana; FARIA FILHO, Luciano; FONSECA, Nelma; LAGES, Rita. (org.). A qualidade da escola pública no Brasil. Belo Horizonte: Mazza, 2012.

PARO, Vitor Henrique. O professor como trabalhador. In. ALMEIDA, Luana; PINO, Ivany; PINTO, José; GOUVEIA, Andréa (Org.). Anais do IV Seminário de Educação Brasileira PNE em foco. Ebook. Campinas: Cedes, v. 1. 2013. p. 957-971.

RAVITCH, Diane. Vida e morte do grande sistema escolar americano. Porto Alegre: Sulina, 2011. 
SANTOS, Juliana; PEREIRA, Marcos; AMORIM, Antonio. Os sujeitos estudantes da EJA. Revista Internacional de Educação de Jovens e Adultos, v. 01, n. 01, p. 122-135, jan./jun. 2018.

SAVIANI, Demerval. Educação. São Paulo: Cortez, Autores Associados, 1983.

SEGUNDA CHAMADA, Direção: Joana Jabace. Criadores: Carla Faour e Julia Spadaccini. Rio de Janeiro: Globo, 2019.

SILVA, Josineide. O cinema na sala de aula. Revista Educação, Guarulhos, v. 5, n. 2, p. 29$35,2010$.

SILVA, Tomaz. Documentos de identidade. 2. ed. Belo Horizonte: Autêntica, 2002.

SOARES, Elza. Comportamento geral. 2019. Disponível em: https://youtu.be/Ttn6Vr3D9Y. Acesso em: 20 nov. 2020.

SOARES, Leôncio. Os desafios da educação de jovens e adultos. Roda de Conversa, programa veiculado pela Rede Minas no dia 29/03/2014. (entrevista, 19':02"). Disponível em: https://www.youtube.com/watch?v=vOyWBZuMHBQ\&t=181s. Acesso em: 14 nov. 2020.

STRELHOW, Thyeles. Breve história sobre a EJA. Revista Histedbr on-line, Campinas, $n$. 38, p. 49-59, jun. 2010.

VANOYE, Francis; GOLIOT-LÉTÉ, Anne. Ensaio sobre análise fílmica. 2. ed. Campinas, SP: Papirus, 1994.

Recebido em março de 2021.

Aprovado em maio de 2021. 